\title{
Culturing the Human Natural Killer Cell Line NK-92 in Interleukin-2 and Interleukin-15 - Implications for Clinical Trials
}

\author{
HEIDI TÖRNROOS, HENRY HÄGERSTRAND and CHRISTER LINDQVIST \\ Cell Biology, Faculty of Natural Sciences and Engineering, Åbo Akademi University, Turku, Finland
}

\begin{abstract}
Background/Aim: The human natural killer cell line NK-92 is increasingly being used in adoptive cell immunotherapies, either in vitro or in animal models transduced with different chimeric antigen receptor (CAR) constructs. Herein, NK-92 cells were analyzed with respect to their proliferation and cytotoxicity, in the presence of interleukin-2 (IL-2) and interleukin-15 (IL-15). Materials and Methods: A time-resolved fluorometric assay (TDA-labeled K562 target cells) was used for measuring the cytotoxic activity of NK-92 cells treated with IL-2, IL-4, IL-7 and/or IL15. Their proliferation, in the presence of these common cytokine receptor $\gamma$ chain $(\gamma c)$-dependent cytokines, was measured by traditional tritiated thymidine $\left(\left[{ }^{3} H\right]-T d R\right)$ incorporation. Results: $I L-2$ and $I L-15$, but not IL-4 or $I L-7$, were able to induce a dose-dependent proliferation of NK-92 cells. IL-15 was, depending on the dose and culture time, up to 10 times more potent compared to corresponding concentrations of $I L-2$, whereas their combination could potentiate the NK-activity almost equally well. No synergistic effects could be noticed with respect to the cytotoxicity and the proliferation of these cells. Conclusion: Data presented here indicate that of the common gamma chain receptor-dependent cytokines tested here, IL-15 alone is able to cultivate and trigger NK-92 cells to such an extent so that they can be used for immune-based cancer therapies. Implications with respect to CAR-transduced NK-92 cells are also discussed.
\end{abstract}

Natural killer (NK) cells are cytotoxic lymphocytes of the innate immune system that were identified in $1975(1,2)$. These cells can lyse virally infected cells as well as cancer

Correspondence to: Christer Lindqvist, Cell Biology, Faculty of Natural Sciences and Engineering, Åbo Akademi University, Tykistökatu 6, FIN-20520, Turku, Finland. Tel: +358 22154053, email: clindqvi@abo.fi

Key Words: Common gamma chain $(\gamma \mathrm{c})$, interleukin-2, interleukin15, natural killer cell, NK-92. cells without prior sensitization (3). This latter observation has made NK cells very attractive for adoptive cell immunotherapies (4). The most common source of NK cells for this purpose has been mononuclear cells from peripheral blood, collected by apheresis using current good manufacturing processes (cGMP). However, the decreased number of collected $\mathrm{NK}$ cells and their limited ex vivo therapeutic activity have forced scientists to use additional sources of NK cells, such as the NK-92 cell line (5-7).

Technological advancements have allowed the expansion of NK-92 cells under GMP and several phase I clinical trials have been conducted using these cells with the aim of treating different types of cancers $(8,9)$. More recently chimeric antigen receptor (CAR)-engineered NK-92 cell lines have also been established for similar purposes (10-12).

NK cells are known for their ability to be kept alive in culture for a long time as well as for their ability to be activated when treated with different types of cytokines (1315). Many of these cytokines contain the common gamma chain as a receptor component, which is crucial for the signal transduction induced by IL-2, IL-4, IL-7, IL-9, IL-15 and IL-21 (16). The aim of this study was to find out which cytokines, alone or in combination, can best activate NK-92 cells. The effects of these cytokines on the proliferation of NK-92 cells were also analyzed. The obtained results are discussed with respect to present and future clinical trials conducted using this cell line as a means of adoptive cell immunotherapy.

\section{Materials and Methods}

Reagents. Recombinant human IL-2 was purchased from R\&D Systems (Minneapolis, MN, USA) and recombinant human IL-4, IL-7 and IL-15 from PeproTech EC (London, UK).

Cell lines. The natural killer cell line NK-92 (ImmuneMedicine, Inc. Vancouver, Canada) and the erythroleukemia NK-sensitive target cell line $\mathrm{K} 562$, were both cultured at $37^{\circ} \mathrm{C}$ in RPMI 1640 (GIBCO, Invitrogen Corp., Paisley, UK) plus $5 \%$ fetal calf serum (FCS; GIBCO) supplemented with $2 \mathrm{mM} \mathrm{L}$-glutamine, $10 \mathrm{U} / \mathrm{ml}$ penicillin $\mathrm{G}$ 
sodium salt (GIBCO) and $10 \mu \mathrm{g} / \mathrm{ml}$ streptomycin sulphate (GIBCO) $(17,18)$. The culture medium of the NK-92 cell line was always supplemented with $20 \mathrm{U} / \mathrm{ml}$ of IL-2, unless otherwise specified.

Labelling of target cells with benzophenonetetracarboxylic dianhydride (BTDA). K562 target cells $\left(1 \times 10^{6}\right.$ in 1ml RPMI 1640 plus $5 \% \mathrm{FCS}$ ) were first pre-incubated for $15 \mathrm{~min}$ at $37^{\circ} \mathrm{C}$ before incubation with $20 \mu \mathrm{M}$ BTDA (PerkinElmer, Inc., Wellesley, MA, USA) for $25 \mathrm{~min}$ at $37^{\circ} \mathrm{C}$. The cells were finally washed 4 times in PBS with mild centrifugation $(306 \times g, 2 \mathrm{~min})$ and were adjusted to $5 \times 10^{4}$ cells $/ \mathrm{ml}$ in RPMI 1640 plus $5 \%$ FCS before being mixed with the effector cells.

Cytotoxicity assay. The cytotoxicity assay was, with minor modifications performed as described earlier (19). In brief, serial dilutions of NK-92 cells in $100 \mu \mathrm{l} /$ well (in triplicates) were added to v-bottomed 96-well microtiter plates (Sarstedt Inc, Nümbrecht, Germany). Effector to target ratios ranged from 10:1 to $1.25: 1$ following the addition of $100 \mu \mathrm{l}\left(5 \times 10^{3}\right)$ of target cells to each well. Following a short centrifugation $(34 \times g, 1 \mathrm{~min})$, the co-cultures were incubated for $2 \mathrm{~h}$ at $37^{\circ} \mathrm{C}$ in a $95 \%$ humidified chamber with $6 \% \mathrm{CO}_{2}$. They were then centrifuged for $5 \mathrm{~min}(688 \times g)$, and $20 \mu \mathrm{l}$ of supernatant from each well were picked and added to $100 \mu \mathrm{l}$ europium solution (Eu) (PerkinElmer, Inc.) contained within flatbottomed 96-well Costar RIA/EIA plates (Corning Inc., Corning, NY, USA). The spontaneous Eu release was determined by incubating the target cells in the culture medium alone instead of having effector cells added, and the maximum Eu release was determined by incubating the target cells in the same medium with $0.5 \%$ Triton X-100. The plates containing Eu and the co-culture supernatants were finally shaken for $15 \mathrm{~min}$ and the fluorescence of the EuTDA chelates formed was measured using a 1420 Victor multi-label counter (PerkinElmer Inc.). Percentages of specific releases were calculated using the following formula:

Specific Release $=($ Experimental release-spontaneous release $) /$ (Maximum release-spontaneous release) $\times 100 \%$

NK-92 proliferation assay. NK-92 cells were grown in $200 \mu \mathrm{l}$ cultures $\left(2.5 \times 10^{5} / \mathrm{ml}\right.$, if not otherwise stated) for indicated periods of time. ${ }^{3} \mathrm{H}$-thymidine incorporation was determined following a 4 $\mathrm{h}$ pulse with $2 \mu \mathrm{Ci} /$ well [methyl- ${ }^{3} \mathrm{H}$ ] Thymidine (Amersham Biosciences, Buckinghamshire, UK, $25 \mathrm{Ci} / \mathrm{mmol}$ ) at the end of the culture. The plates were subsequently stored overnight at $-70^{\circ} \mathrm{C}$, and then were thawed and collected using a semiautomatic cell harvester (Skatron, Lier, Norway). Recovered radioactivity was counted using a liquid scintillation counter (Wallac 1410 Liquid scintillation counter; Wallac Oy, Turku, Finland).

Statistical analysis. Comparisons between treatments were performed using independent sample $t$-tests (SPSS 23.0 software; SPSS Inc., Chicago, IL, USA). All $p$-values less than 0.05 were considered statistically significant.

\section{Results}

NK-92 cells proliferate in the presence of IL-2 and IL-15, but not of $I L-4$ and $I L-7$. Figure 1 shows the NK-92 cell proliferation in the presence of the common gamma chain receptor-dependent cytokines IL-2, IL-4, IL-7 and IL-15 at

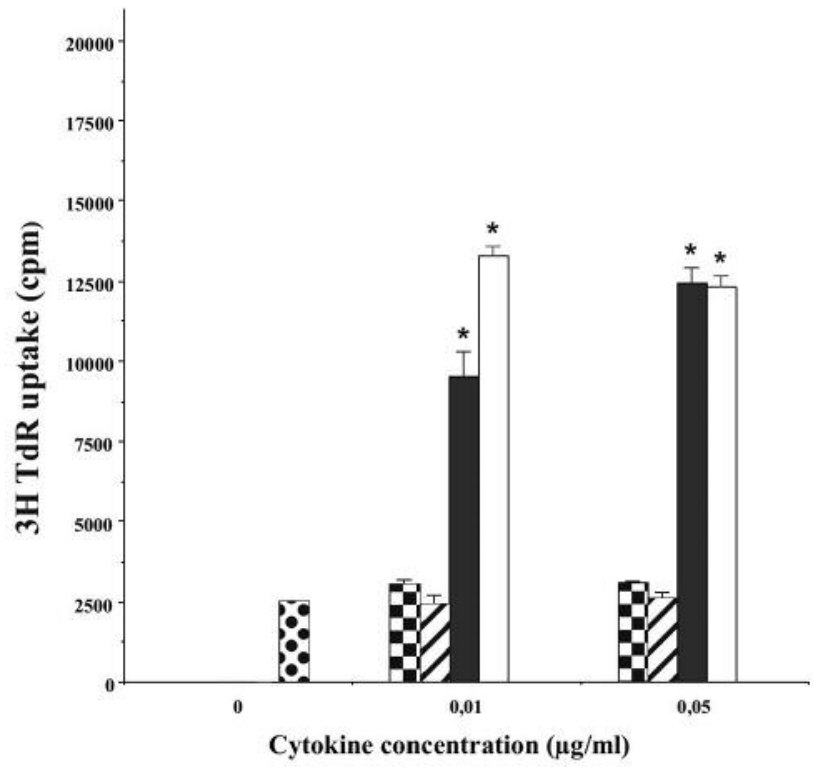

Figure 1. Proliferation of NK-92 cells in the presence of $I L-2, I L-4, I L-$ 7 and $I L-15 . N K-92$ cells were cultured in the presence of indicated concentrations of IL-2 (filled), IL-4 (squares), IL-7 (stripes) or IL-15 (open) and in medium alone (black circles; $2542 \pm 149 \mathrm{cpm}$ ). [3H] thymidine uptake was measured after $48 \mathrm{~h}$ of culture. Results are expressed as means $\pm S D$ and are representative of three independent experiments. ${ }^{*} p<0.05$ as compared to medium alone.

concentrations of $0.01 \mu \mathrm{g} / \mathrm{ml}$ and $0.05 \mu \mathrm{g} / \mathrm{ml}$. Both IL-4 and IL-7 did not alter proliferation of NK-92 cells, compared to the control (untreated) group. However, cell proliferation was significantly induced by the cytokines IL-2 $(0.01 \mu \mathrm{g} / \mathrm{ml}$ : $9496 \pm 802,0.05 \mu \mathrm{g} / \mathrm{ml}: 12457 \pm 453 \mathrm{cpm} ; p<0.05)$ and IL-15 $(0.01 \mu \mathrm{g} / \mathrm{ml}: 13287 \pm 284,0.05 \mu \mathrm{g} / \mathrm{ml}: 12326 \pm 315 \mathrm{cpm}$; $p<0.05)$ compared to the control $(2689 \pm 299 \mathrm{cpm})$.

Comparison between the IL-2- and the IL-15-dependent proliferation at $48-96 \mathrm{~h}$ indicated that IL-15 is much more potent at all the time points analyzed. In fact, only $0.0005 \mu \mathrm{g} / \mathrm{ml}$ of IL-15 was enough to induce maximal cell proliferation at 48 $\mathrm{h}$, whereas the concentration of IL-2 with the same effect was $0.01 \mu \mathrm{g} / \mathrm{ml}$ (Figure 2A). At $72 \mathrm{~h}$ of treatment, maximal cell proliferation was reached by IL-15 at the highest concentration $(0.01 \mu \mathrm{g} / \mathrm{ml})$, whereas IL-2 at the same concentration induced less than $50 \%$ of maximal proliferation (Figure 2B). Prolonged proliferation was observed at $96 \mathrm{~h}$ in the presence of as little as $0.05 \mu \mathrm{g} / \mathrm{ml}$ of IL-15, while no significant increase in NK-92 cell proliferation was observed at this time with $0.01 \mu \mathrm{g} / \mathrm{ml}$ of IL-2 in the medium (Figure 2C).

No synergistic proliferation effect was induced by IL-2 and $I L-15$. Figure $3 \mathrm{~A}$ shows a dose-dependent IL-2-induced proliferation of NK-92 cells at $48 \mathrm{~h}$. Treatment of cells with 

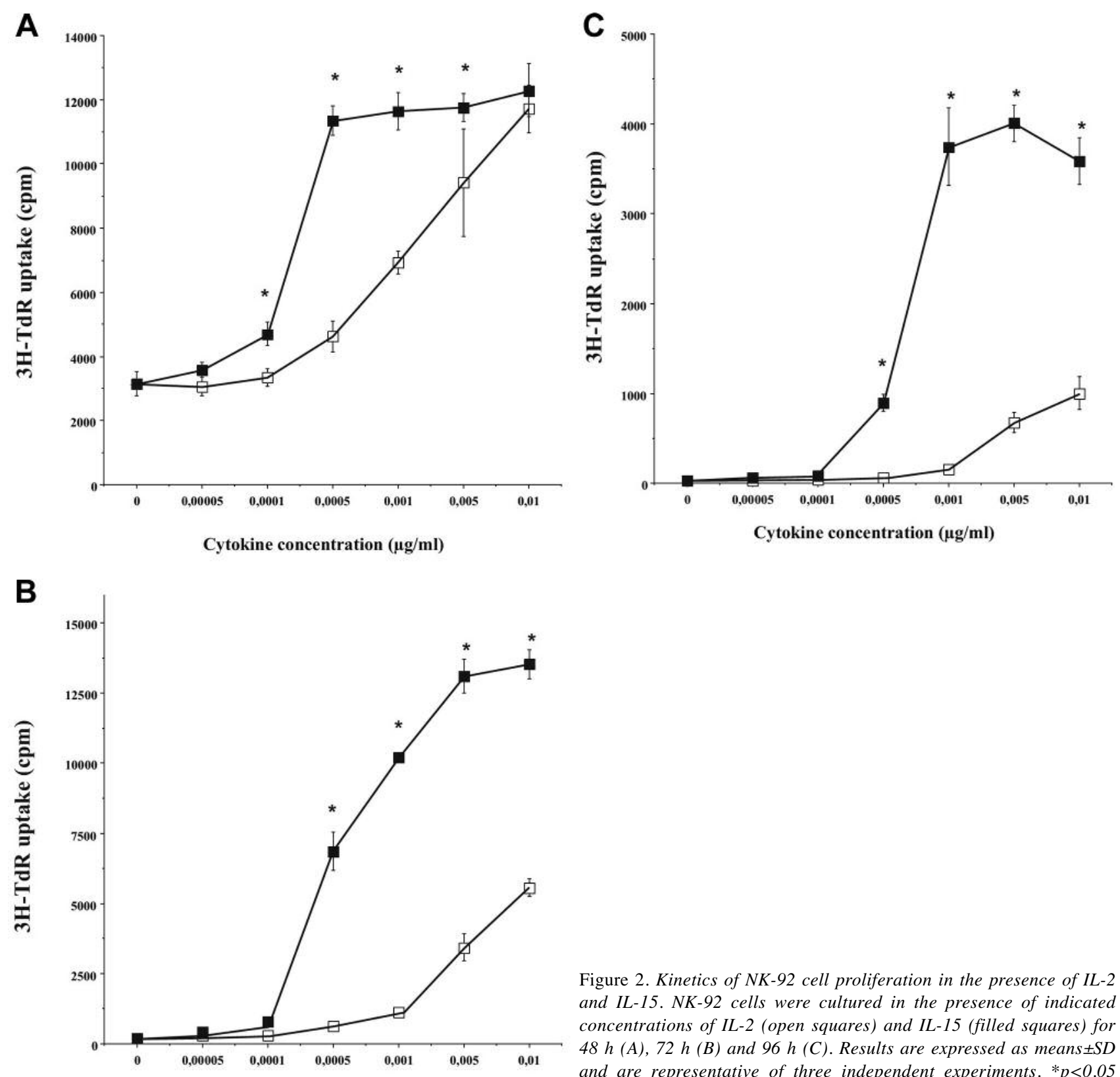

Cytokine concentration $(\mu \mathrm{g} / \mathrm{ml})$

Figure 2. Kinetics of NK-92 cell proliferation in the presence of IL-2 and IL-15. NK-92 cells were cultured in the presence of indicated concentrations of IL-2 (open squares) and IL-15 (filled squares) for $48 h(A), 72 h(B)$ and $96 h(C)$. Results are expressed as means $\pm S D$ and are representative of three independent experiments. $* p<0.05$ compared to IL-2.

IL-15 $(0.005 \mu \mathrm{g} / \mathrm{ml})$ combined with IL-2 $(0.001-0.01 \mu \mathrm{g} / \mathrm{ml})$ did not alter the proliferation rate to any extent compared to the IL-15 alone $(19744 \pm 1185 \mathrm{cpm})$. Similar results were observed at $72 \mathrm{~h}$ (Figure 3B).

Both IL-2 and IL-15 can potentiate the NK activity equally efficiently. The clear difference noticed between IL-2- and IL-15-mediated proliferation (Figures 2A-C), suggested a similar trend with their potential to trigger the cytotoxic activity of NK-92 cells. However, when NK-92 cells were pretreated for $48 \mathrm{~h}$ in the presence of either IL-2 or IL-15 at $0.01 \mu \mathrm{g} / \mathrm{ml}$ and $0.1 \mu \mathrm{g} / \mathrm{ml}$, the NK lytic activity was in the range of $85-90 \%$ (K562:NK-92 [1:5] cell ratio). Other targetto-effector ratios did not alter the NK activity to any great extent, regardless of whether IL-2 or IL-15 was present in the culture medium (Table I).

No synergistic potentiation of the NK activity with IL-2 and $I L-15$. Although no synergistic proliferation effects were observed with IL-2 and IL-15, their combined effects on the 
Table I. Potentiation of the NK-92 cell activity with interleukin-2 (IL-2) and IL-15.

\begin{tabular}{|c|c|c|c|c|c|}
\hline \multirow{2}{*}{$\begin{array}{l}\text { Pretreatmen } \\
\text { Cytokine }\end{array}$} & \multirow[b]{2}{*}{ Concentration $(\mu \mathrm{g} / \mathrm{ml})$} & \multicolumn{4}{|c|}{ Target to effector cell ratio } \\
\hline & & $1: 1.25$ & $1: 2.5$ & $1: 5$ & $1: 10$ \\
\hline Medium & 0 & $37.6 \pm 0.89$ & $56.7 \pm 4.61$ & $67.8 \pm 3.26$ & $89.2 \pm 10.4$ \\
\hline IL-2 & 0.01 & $71.7 \pm 6.24$ & $88.5 \pm 3.46$ & $91.5 \pm 7.01$ & $100 \pm 14.7$ \\
\hline IL-2 & 0.1 & $81.3 \pm 0.98$ & $93.8 \pm 3.58$ & $95.8 \pm 5.84$ & $100 \pm 11.5$ \\
\hline IL-15 & 0.01 & $67.3 \pm 2.20$ & $83.5 \pm 2.53$ & $84.1 \pm 5.20$ & $95.7 \pm 3.04$ \\
\hline IL-15 & 0.1 & $71.0 \pm 6.00$ & $84.3 \pm 4.46$ & $85.7 \pm 6.49$ & $97.8 \pm 2.60$ \\
\hline
\end{tabular}

aNK-92 cells $\left(1.25 \times 10^{5}\right.$ cells $\left./ \mathrm{ml}\right)$ were first pretreated, with the indicated concentrations of IL-2 or IL-15, or with medium (control) for $48 \mathrm{~h}$ before the cytotoxicity assay with K562 as target cells. The results (\% lysis) are expressed as means \pm SD and are representative of three independent experiments.
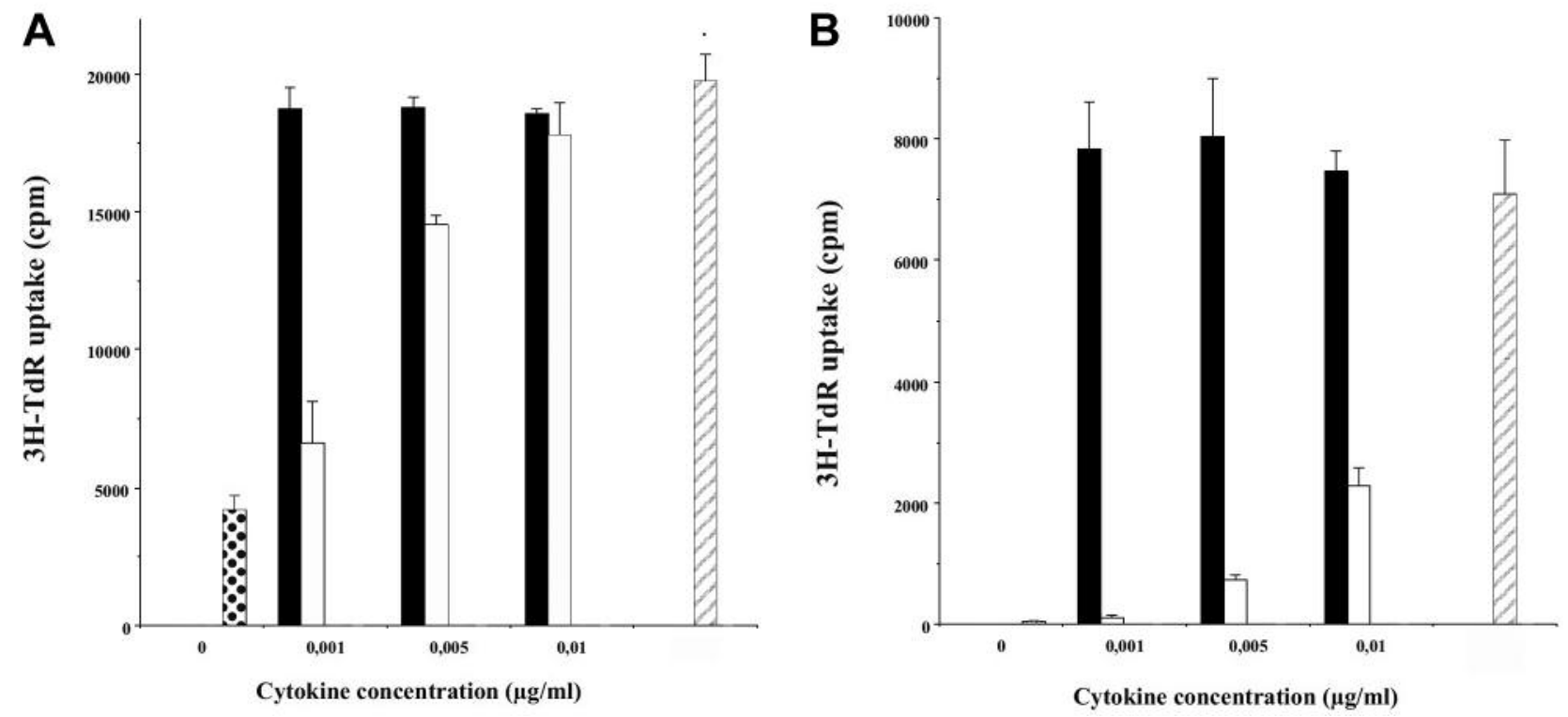

Figure 3. No synergistic effect of IL-2 and IL-15 on the NK-92 cell proliferation. NK-92 cells $(2 \times 105 / m l)$ were cultured for $48 h(A)$ or $72 h(B)$ in the presence of indicated concentrations of IL-2 alone (open) or together with $0.005 \mu \mathrm{g} / \mathrm{ml}$ of IL-15 (filled). Culture for $48 \mathrm{~h}$ in $0.005 \mu \mathrm{g} / \mathrm{ml}$ of IL$15 ; 19744 \pm 1185$ (stripes), medium only; $4210 \pm 489$ (black circles) and $72 \mathrm{~h}$ culture in only $0.005 \mu \mathrm{g} / \mathrm{ml}$ of IL-15; $6988 \pm 1158$ (stripes), medium only; $51 \pm 13$ (black circles). Results are expressed as means $\pm S D$ and are representative of three independent experiments.

NK activity could be different. To test this, NK-92 cells were cultured for $48 \mathrm{~h}$ in the presence of IL-2 or IL-15 alone, or combined at a concentration of $0.1 \mu \mathrm{g} / \mathrm{ml}$. Pretreating the cells with IL-2 or IL-15 dramatically triggered the NK activity compared to effector cells in medium alone. We observed an almost $40 \%$ increase in the lytic activity of NK-92 cells in the presence of these cytokines, independently of the target-toeffector cell ratio analyzed. However, combination of the two cytokines did not improve or alter the NK activity any further (Figure 4).

\section{Discussion}

Since the early eighties, NK cells are known to be activated by "soluble factors", which were later defined as cytokines (20). A great number of cytokines has since then been analyzed with respect to their effect on the activity, proliferation, production and secretion of cytotoxic granules of the NK cells $(13-15,21)$. Since NK cells have the ability to kill tumor cells without prior sensitization and restriction of human leukocyte antigens (HLA), they have been 


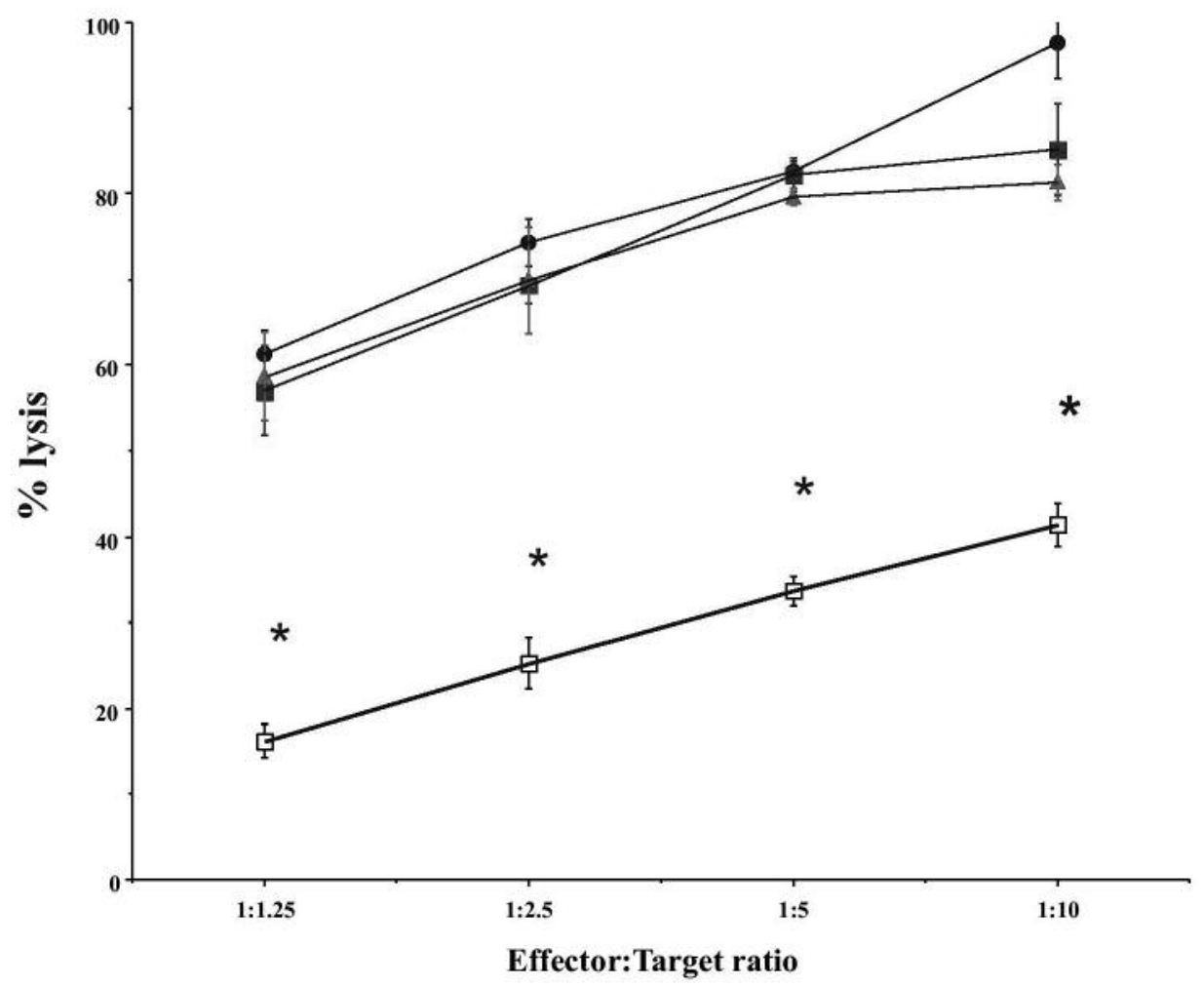

Figure 4. No synergistic effect of IL-2 and IL-15 on the NK-92 activity. NK-92 cells (1.25 x 105/ml) were cultured with $0.1 \mu \mathrm{g} / \mathrm{ml}$ of IL-2 (filled circles), $0.1 \mu \mathrm{g} / \mathrm{ml}$ of IL-15 (filled squares), $0.1 \mu \mathrm{g} / \mathrm{ml}$ of IL-2+0.1 $\mathrm{gg} / \mathrm{ml}$ of IL-15 (filled triangels) or in medium alone (open squares) for $48 \mathrm{~h}$ and were subsequently analyzed for their NK activity against $K 562$ cells. Results are expressed as means $\pm S D$ and are representative of three independent experiments. ${ }^{*} p<0.05$ compared to medium alone.

successfully used, albeit to a limited extent, in anticancer immunotherapy $(6,22)$. The next step in adoptive cellular immunotherapy is to use more robust NK cell lines, such as NK-92. However, an even more encouraging future awaits with the development and use of CAR-engineered NK cell lines (11). More specifically, it has been demonstrated that CAR-expressing NK-92 cells exert enhanced anti-tumor effects and selective cytotoxicity against tumor cells. Moreover, CAR expression is more stable and homogeneous in NK-92 cells, which might further improve the outcome of an in vivo treatment $(23,24)$.

In order to successfully perform an ex vivo expansion of NK cells and in particular of NK-92 cells, several parameters have to be evaluated and monitored. It is evident that IL-2 and especially IL-15 are crucial for these cells' expansion, while NK-92 cells cannot be maintained in IL-4 and IL-7 containing media, despite the presence of the common gamma chain receptor in all these cytokines, an observation also partly confirmed by Gong et al. and Törnroos et al. $(17,25)$. The important role of IL-2 and IL15 with respect to the survival of NK cells in general, has been previously well-described by Carson et al., although information regarding IL-15-induced proliferation of NK92 cells is limited $(21,26,27)$. Our data here clearly demonstrate that IL-15 is much more potent at any given concentration compared to IL-2. It is, therefore, of importance that this great difference between the two cytokines is taken into consideration in the future clinical adoptive cellular immunotherapy trials, especially if using NK-92 cells. Trials reported so far have only used IL-2 for the ex vivo expansion of these cells $(8,9)$.

Interestingly, both IL-2 and IL-15 were able to potentiate the activity of NK-92 cells independently of cytokine concentrations and effector-to-target ratios (Table I). Similar results have also been reported for NK-cells isolated from human peripheral blood (28). However, our data on proliferation and activation efficiency of NK-92 cells show no synergistic effect when combining these two cytokines. These results can benefit the scientific community as well as patients in both technical and financial terms, as the ex vivo expansion of NK-92 cells can be done in IL-15-containing media alone. Additional studies need to be set in order to engineer CAR NK-92 cells transfected with the $I L-15$ gene that can be safely used in clinical trials. 


\section{References}

1 Kiessling R, Klein E and Wigzell H: "Natural" killer cells in the mouse. I. Cytotoxic cells with specificity for mouse Moloney leukemia cells. Specificity and distribution according to genotype. Eur J Immunol 5: 112-117, 1975.

2 Herbermann RB, Nunn ME and Lavrin DH: Natural cytotoxic reactivity of mouse lymphoid cells against syngeneic and allogeneic tumors. I. Distribution of reactivity and specificity. Int J Cancer 16: 216-229, 1975.

3 Trinchieri G: Biology of natural killer cells. Adv Immunol 47: 187-376, 1989.

4 Uppendahl LD, Dahl CM, Miller JS, Felices M and Geller MA: Natural killer cell-based immunotherapy in gynecologic malignancy: A review. Front Immunol 8: 1825, 2018.

5 Koepsell SA, Miller JS and McKenna DH Jr.: Natural killer cells: a review of manufacturing and clinical utility. The Transfusion 53: 404-410, 2013.

6 Galluzzi L, Vacchelli E, Bravo-San Pedro JM, Buqué A, Senovilla L, Baracco EE, Bloy N, Castoldi F, Abastado JP, Agostinis P, Apte RN, Aranda F, Ayyoub M, Beckhove P, Blay JY, Bracci L, Caignard A, Castelli C, Cavallo F, Celis E, Cerundolo V, Clayton A, Colombo MP, Coussens L, Dhodapkar MV, Eggermont AM, Fearon DT, Fridman WH, Fučíková J, Gabrilovich DI, Galon J, Garg A, Ghiringhelli F, Giaccone G, Gilboa E, Gnjatic S, Hoos A, Hosmalin A, Jäger D, Kalinski P, Kärre K, Kepp O, Kiessling R, Kirkwood JM, Klein E, Knuth A, Lewis CE, Liblau R, Lotze MT, Lugli E, Mach JP, Mattei F, Mavilio D, Melero I, Melief CJ, Mittendorf EA, Moretta L, Odunsi A, Okada H, Palucka AK, Peter ME, Pienta KJ, Porgador A, Prendergast GC, Rabinovich GA, Restifo NP, Rizvi N, Sautès-Fridman C, Schreiber H, Seliger B, Shiku H, SilvaSantos B, Smyth MJ, Speiser DE, Spisek R, Srivastava PK, Talmadge JE, Tartour E, Van Der Burg SH, Van Den Eynde BJ, Vile R, Wagner H, Weber JS, Whiteside TL, Wolchok JD, Zitvogel L, Zou W and Kroemer G: Classification of current anticancer immunotherapies. Oncotarget 5: 12472-12508, 2014.

7 Suck G, Odendahl M, Nowakowska P, Seidl C, Wels WS, Klingemann HG and Tonn T: NK-92: an 'off-the-shelf therapeutic' for adoptive natural killer cell-based cancer immunotherapy. Cancer Immunol Immunother 65: 485-492, 2016.

8 Arai S, Meagher R, Swearingen M, Myint H, Rich E, Martinsson $\mathrm{J}$ and Klingemann $\mathrm{H}$ : Infusion of the allogeneic cell line NK-92 in patients with advanced renal cell cancer or melanoma: a phase I trial. Cytotherapy 10: 625-632, 2008.

9 Tonn T, Schwabe D, Klingemann HG, Becker S, Esser R, Koehl U, Suttorp M, Seifried E, Ottmann OG and Bug G: Treatment of patients with advanced cancer with the natural killer cell line NK-92. Cytotherapy 15: 1563-1570, 2013.

10 Tang X, Yang L, Li Z, Nalin AP, Dai H, Xu T, Yin J, You F, Zhu M, Shen W, Chen G, Zhu X, Wu D and Yu J: First-in-man clinical trial of CAR NK-92 cells: safety test of CD33-CAR NK92 cells in patients with relapsed and refractory acute myeloid leukemia. Am J Cancer Res 8: 1083-1089, 2018.

11 Han J, Chu J, Keung Chan W, Zhang J, Wang Y, Cohen JB, Victor A, Meisen WH, Kim SH, Grandi P, Wang QE, He X, Nakano I, Chiocca EA, Glorioso JC 3rd, Kaur B, Caligiuri MA and $\mathrm{Yu}$ J: CAR-Engineered NK cells targeting wild-type EGFR and EGFRvIII enhance killing of glioblastoma and patientderived glioblastoma stem cells. Sci Rep 5: 11483, 2015.
12 Hermanson DL and Kaufman DS: Utilizing chimeric antigen receptors to direct natural killer cell activity. Front Immunol 6: $1-6,2015$

$13 \mathrm{Wu}$ Y, Tian Z and Wei H: Developmental and functional control of natural killer cells by cytokines. Front Immunol 4: 930, 2017.

14 Strengell M, Matikainen S, Siren J, Lehtonen A, Foster D, Julkunen I and Sareneva T: IL-21 in synergy with IL-15 or IL18 enhances IFN- $\gamma$ production in human NK and $\mathrm{T}$ cells. $\mathrm{J}$ Immunol 170: 5464-5469, 2003.

15 Hietanen T, Kapanen M and Kellokumpu-Lehtinen PL: natural killer cell viability after hyperthermia alone or combined with radiotherapy with or without cytokines. Anticancer Res 38: 655-663, 2018.

16 Pulliam SR, Uzhachenko RV, Adunyah SE and Shanker A: Common gamma chain cytokines in combinatorial immune strategies against cancer. Immunol Lett 169: 61-72, 2016.

17 Gong J-H, Maki G and Klingemann HG: Characterization of a human cell line (NK-92) with phenotypocal and functional characteristics of activated natural killer cells. Leukemia 8 : 652658, 1994.

18 Lozzio CB and Lozzio B: Human chronic myelogenous leukemia cell-line with positive Philadelphia chromosome. Blood 45: 321-324, 1975.

19 Blomberg K, Hautala R, Lövgren J, Mukkala V-M, Lindqvist C and Åkerman K: Time resolved fluorometric assay for natural killer activity using target cells labelled with a fluorescence enhancing ligand. J Immunol Meth 193: 199-206, 1996.

20 Henney CS, Kuribayashi K, Kern DE and Gillis S: Interleukin-2 augments natural killer cell activity. Nature 291: 335-338, 1981.

21 Samara P, Skopeliti M, Tsiatas ML, Georgaki S, Gouloumis C, Voelter W, Dimopoulos AM, Bamias A and Tsitsilonis OE: A cytokine cocktail augments the efficacy of adoptive NK-92 cell therapy against mouse xenografts of human cancer. Anticancer Res 36: 3373-3382, 2016.

22 Vivier E, Raulet DH, Moretta A, Caligiuri MA, Zitvogel L, Lanier LL, Yokoyama WM and Ugolini S: Innate or adaptive immunity? The example of natural killer cells. Science 331: 44-49, 2011.

23 Wang W-n, Zhou G-y and Zhang W-1: NK-92 cell, another ideal carrier for chimeric antigen receptor. Immunotherapy 9: 1-13, 2017.

24 Klingemann H, Boissel L and Toneguzzo F: Natural killer cells for immunotherapy - advantages of the NK-92 cell line over blood NK cells. Front Immunol 14: 91, 2016.

25 Törnroos H, Nordström T and Lindqvist C: Thymic stromal lymphopoietin augments the cytolytic activity of the human natural killer cell line NK-92. APMIS 115: 948-955, 2007.

26 Carson WE, Fehniger TA, Haldar S, Eckhert K, Lindemann MJ, Lai CF, Croce CM, Baumann $\mathrm{H}$ and Caligiuri MA: A potential role for interleukin-15 in the regulation of human natural killer cell survival. J Clin Invest 99: 937-943, 1997.

27 Sahm C, Schönfeld K and Wels WS: Expression of IL-15 in NK cells results in rapid enrichment and selective cytotoxicity of gene-modified effectors that carry a tumor-specific antigen receptor. Cancer Immunol Immunother 61: 1451-1461, 2012.

28 Sun R, Fan J, Wei H, Zhang C and Tian Z: Use of interleukin15 for preparation of adherent NK cells from human peripheral blood: comparison with interleukin-2. J Immunol Methods 279: 79-90, 2003.

Received October 16, 2018

Revised November 17, 2018

Accepted November 21, 2018 